\title{
Bolivian river dolphin site preference in the middle-section of Mamoré River, upper Madeira river basin, Bolivia
}

\author{
Enzo Aliaga- Rossel ${ }^{1 *}$, and Luis A. Guizada Duran ${ }^{1}$ \\ ${ }^{1}$ Colección Boliviana de Fauna, Institute of Ecology, Universidad Mayor de San Andrés, 27 st Campus Universitario, Cota Cota, La \\ Paz, Bolivia. E-mail: ealiagar@hotmail.com (EA-R), L.guizada.duran@gmail.com (LGD). \\ *Corresponding autor.
}

\begin{abstract}
The South American river dolphins of genus Inia are distributed throughout the Amazon, Orinoco and Araguaia-Tocantins basins. They are categorized as Endangered and the knowledge on their basic ecology is still scarce. Therefore, investigation efforts must contribute to the knowledge and conservation of these species in their area of distribution. For the Bolivian river dolphin we used a database of 10 years of upstream and downstream surveys, accumulating approximately 6,100 km of double routes from three main rivers of the Upper Madeira River basin (Ibare, Mamoré and Tijamuchi) by following standardized methods where each encounter with a single or a group of river dolphins was registered. Preferred sites by Bolivian river dolphin were based on Kernel density estimation. This methodology considers the accumulated data of georeferenced sightings, generating a map of probability of occurrence in each river. In the three rivers, the accumulated density of sightings is concentrated in meanders and confluences, resulting in a high probability of sighting Bolivian river dolphin in these habitats. It was also identified that the number of Bolivian river dolphin sightings decreased over time in the upper Tijamuchi River. The Bolivian river dolphin preferred both meanders and confluence habitats. Between the lbare and Tijamuchi rivers (Mamoré sub- basin), the distribution of the species tended to be more uniform. According to these results, it is important to reinforce the management of the lbare-Mamoré municipal protected area, since important Bolivian river dolphin populations are concentrated there. Same trend was also shown in the lower-middle zone of the Tijamuchi River, suggesting the need of implementing conservation strategies in this area, where currently there are none.
\end{abstract}

Los delfines de río sudamericanos del género Inia se distribuyen por las cuencas del Amazonas, Orinoco y Araguaia-Tocantins, se clasifican como en peligro de extinción y el conocimiento sobre su ecología básica aún es escaso. Por lo tanto, las investigaciones deben contribuir a la conservación y el conocimiento de estas especies en su área de distribución. Para el delfín del río boliviano, utilizamos una base de datos de 10 años de recorridos río aguas-arriba y río aguas-abajo, acumulando aproximadamente 6,100 km de rutas dobles en tres ríos principales en la subcuenca alta del río Madeira (Ibare, Mamoré y Tijamuchi). Siguiendo los métodos estandarizados cada encuentro con uno o un grupo de delfines de río fue registrado. La identificación de los sitios preferidos por los bufeos fue estimada por la densidad del Kernel. Esta metodología considera los datos acumulados de avistamientos georreferenciados que generan un mapa de probabilidad de ocurrencia en cada río. En los tres ríos, la densidad acumulada de avistamientos se concentra en meandros y confluencias, lo que resulta en una alta probabilidad de ver bufeos en estos hábitats. También se determinó que los avistamientos de bufeos han disminuido en la parte superior del río Tijamuchi. Los bufeos prefirieron los hábitats de meandros y de confluencia; entre los ríos Ibare y Tijamuchi (cuenca Mamoré), la distribución de las especies tendió a ser más uniforme. Según estos resultados, es importante reforzar la gestión del área protegida municipal de Ibare-Mamoré, ya que allí se concentran importantes poblaciones de bufeo. La misma tendencia también se mostró en la zona media-baja del río Tijamuchi, lo que sugiere la necesidad de implementar estrategias de conservación en esta área, donde actualmente todavía no se ha declarado ninguna.

Keywords: bufeo; conservation area; kernel density; occurrence probability; preferred pites.

(c) 2020 Asociación Mexicana de Mastozoología, www.mastozoologiamexicana.or

\section{Introduction}

South American river dolphins of genus Inia (family Iniidae) are distributed throughout the Amazon, the Orinoco and the Araguaia-Tocantins basins (Trujillo et al. 2010a; Trujillo et al. 2010a). Like most freshwater dolphins, they are categorized as Endangered (da Silva et al. 2018). River dolphins are threatened by water pollution, habitat degradation, deforestation, heavy boat traffic, overfishing, the construction of hydroelectric dams, bycatch and directed capture for illegal uses, e. g. production of oil used as traditional remedy or as bait for fishes such as blanquillo (Calophysus macropterus, Hypophthalmus sp.; Reeves and Leatherwood 1994; Aliaga-Rossel and McGuire 2010; Trujillo et al. 2010b; Smith et al. 2012; Mosquera-Guerra et al. 2015).

The family Iniidae is restricted to freshwater environments, occupying the main courses of rivers, lagoons, confluences, and streams. During high water season, they tend to disperse and occupy environments such as flooded forest, small tributary rivers, seasonal isolated lagoons and other aquatic habitats of the flooded-lowlands (Pilleri and Gihr 1977; Best and da Silva 1993; Aliaga-Rossel 2002). Most of the studies focused on Inia population estimations and briefly mentioned a habitat preference, with a greater number of encounters in confluence, tributary, and lagoon areas (McGuire and Winemiller 1998; Aliaga-Rossel 2002; Martin and da Silva. 2004a, b; Martin et al. 2004; McGuire and Aliaga-Rossel 2007; Gómez-Salazar et al. 2011, 2012b; Guizada and Aliaga-Rossel 2016; Trujillo et al. 2019).

Although limited, knowledge about habitat use, habitat preferences or occurrence of Inia varies according to spatial and temporal scales. The most outstanding studies are those from the long-term (more than 25 years) moni- 
toring project called Projeto Boto in the Mamirauá Sustainable Development Reserve (central Amazon), specifically with techniques of photo identification (da Silva and Martin 2000; Martin and da Silva 2004a) and telemetry (Martin and da Silva 2004b).

The Bolivian river dolphin (Inia boliviensis) is locally known as "bufeo", which is the only recognized name of these animals in Bolivia. Therefore, throughout this report we use this local name, which contrasts to the term used by the International Whaling Committee (IWC), or 'boto' (Aliaga-Rossel and Guizada 2020). The Bolivian bufeo was declared a national and regional natural heritage, despite of this declarations, the threats over their populations are increasing. In order to contribute to the understanding of habitat preferences of the bufeo in a complex of rivers located in the middle region of the Mamoré River, our study focuses on and analyzes georeferenced encounters with this species based on monitoring efforts conducted between 2008 and 2019.

\section{Materials and Methods}

The study area is a complex of rivers in the middle-section of the Mamoré River, upper Madeira River basin, department of Beni, Bolivia. We studied the Ibare $(47.9 \mathrm{~km})$, Mamoré $(128.3 \mathrm{~km})$ and Tijamuchi $(169.4 \mathrm{~km})$ rivers with a total extension of $345.8 \mathrm{~km}$, or approximately $80 \mathrm{~km}^{2}$ (Figure 1). The area corresponds to flood plains savannas called Llanos de Moxos. The Mamoré River is a whitewater river of Andean origin, with water typically dark or yellowishbrown color with little transparency, due to the large quantity of suspended sediment (Guyot 1993; Albert and Reis 2011). While Ibare and Tijamuchi are black and clear water tributaries, originating in the flooded forest plains, with few suspended sediments (Guyot 1993; Albert and Reis 2011), both rivers are Mamoré confluents. We defined confluences when two or more bodies of water meet; these are areas on the river where a tributary discharge its water into a main river (Aliaga-Rossel and Guizada 2020). Finally, we defined curves and meanders, which are places where the riverbed is wide and has a higher than average current; usually the water flow is fastest along the outside bend of a meander, and slowest on the inside bend, where bufeos prefer to stay (Albert and Reis 2011; Aliaga-Rossel and Guizada 2020).

During the high water-level season, Ibare and Tijamuchi rivers showed an average width of $\sim 200 \mathrm{~m}$, while during the low water-level season width decreased to approximately half (60 to $70 \mathrm{~m}$ ). On the other hand, the Mamoré River (one of the most important rivers in Bolivia) showed an average width above $200 \mathrm{~m}$, reaching more than $400 \mathrm{~m}$ during the high water-level season. The vegetation along the riverbanks is characteristic of a tropical gallery forest. Much of the region is flooded during the high water season. The average air temperature for the region is $26.5^{\circ} \mathrm{C}$. The relative humidity ranges between $64 \%$ in August and $77 \%$ in January and February (Aliaga Rossel et al. 2006).
Human settlements predominate along Ibare and Mamoré rivers, while cattle ranching is the most important activity in the Tijamuchi River. Logging and other extractive activities such as fishing, for both subsistence and commercialization, are the main activities in the area. Local human communities use the water courses as main transport in Beni, where boat traffic in the last years has also increased due to tourism activities (Aliaga-Rossel et al. 2014).

Bufeo sightings. Bufeo encounters were recorded from 2008 to 2019 using the standardized method of linear transect (for main rivers) and 100 strip-band transect (for tributaries), depending on the width and water levels; these methods are widely used for river dolphin surveys (Aliaga-Rossel 2002; Gómez-Salazar et al. 2012b). Sightings covered $\sim 50 \mathrm{~km}$ of the lbare (lb) River with 14 surveys total, $\sim 130 \mathrm{~km}$ of the Mamoré River (Ma) with a total of eight surveys, and $\sim 170 \mathrm{~km}$ of the Tijamuchi (Tj) river with eight surveys (30 transect surveys total). For each transect survey, a similar size vessel was used: 15 to $25 \mathrm{~m}$ long and 1.5 to $2.5 \mathrm{~m}$ of height was the minimum used for the data collection. On each transect there were three or four observers at the bow and one assistant to register bufeo encounters. Observers were responsible for recording each dolphin's sighting time, habitat associated, and its geographical position using GPS. All observations were made when optimal visibility was available, from 7:00 to 17:00, with an approximately one-hour lunch break, when the vessel was stopped until resuming effort.

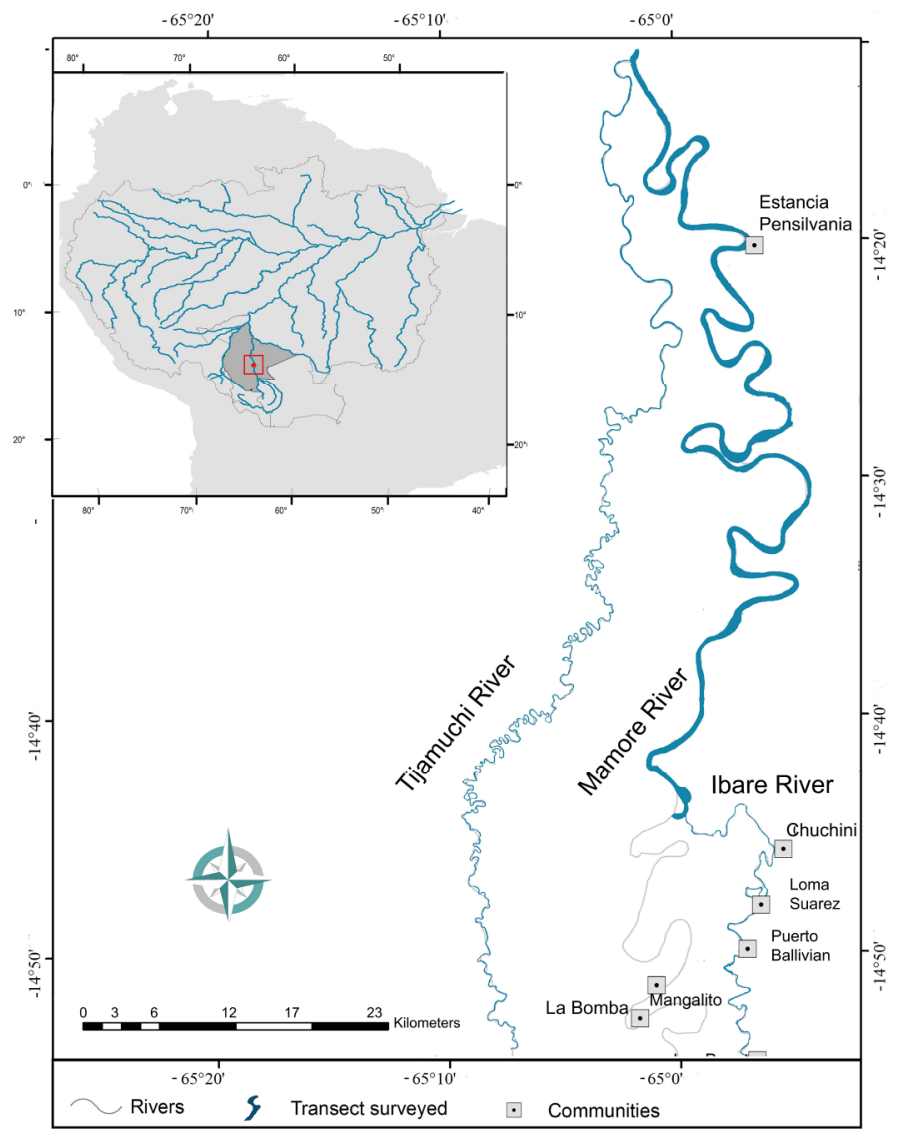

Figure 1. Study site, Ibare, Tijamuchi- Mamoré river complex sampled for river dolphins 2008-2019. Upper Madeira River Basin, Bolivia. 
Data analysis. All spatial analyses were performed using ArcGis 10.5 software. For each georeferenced point in a tributary (lbare and Tijamuchi) a $150 \mathrm{~m}$ buffer area was applied, and $200 \mathrm{~m}$ to the main Mamoré River. With these polygons, an image per river per year (IRY), with a cell size of $150 \mathrm{~m}$, was created based on the number of bufeos as cell value. For NoData values, they were reclassified to value 0 to perform the raster calculator tool works. All images of each river were added to have a cumulative image. The final image was transformed to a layer of points based on the number of recorded bufeos accumulated along the years in each cell using raster to point tool. Kernel Density was applied on the resulting point layer using the quantity parameter registered per cell as population field, $150 \mathrm{~m}$ as the size cells, and a calculated search radius of 690.9 $\mathrm{m}$ corresponding to an area of $1.5 \mathrm{~km}^{2}$ according to the parameter of average movement of individuals (McGuire and Henningsen 2007).

From the resulting raster, the probabilities of a normal distribution in each cell were obtained to measure the probability of occurrence of bufeos at a given site. The probabilities were calculated with raster package and dependencies on $R$ ( $\mathrm{R}$ Core Team 2017). After loading the Kernel layer in raster format, the probability values of a normal distribution on the layer were obtained with the pnorm function. It was specified that pnorm consider the raster mean and twice the standard deviation. Subsequently, the values function was used to obtain the values for each cell of a new image. Finally, the writeRaster function was used to produce an image with the observation probabilities per cell (script details in appendix 1)

To identify the sites that had constant presence of bufeos over time, IRY raster values were reclassified to absence-presence values ( 0 to 1 ) giving an individual condition to each year; which means that if a river had data for four years, the values for each year are 1 (year 1), 10 (year 2), 100 (year 3), and 1000 (year 4). The sum of images per river was performed and the values were reclassified according to the occurrence in number of years, either only one year or several.

\section{Results}

The sites that possess the highest density of points of bufeos are meanders and river confluences, clearly represented in maps (Figure 2). Ibare River posesses 47 meanders along the sampled stretch. In only three $(6.4 \%)$ of those bufeos have never been registered, and in five $(10.6 \%)$ the density of recorded points decreases (spatially not temporarily). The segment of Mamoré River studied possesses 24 rivercurves; in all of them, bufeos have been registered. On the other hand, in three $(12.5 \%)$ of those the density of occurrence decreased over time. Tijamuchi river has 192 curves; in ten (5.2\%) the density becomes null, and in 37 (19.3\%) the density decreased during time (Figures 2, 3). Based on the density points of bufeo encounters and records, the probability map showed values from $50 \%$ of probability (there may or may not be bufeos there) to higher probability in those places where the density reached $100 \%$. Finally, accumulative occurrence maps (Figure 3) showed that there are places where bufeos were sighted in a single year of sampling. Nevertheless, there are confluences where bufeos were recorded in more than one year of sampling, and it is interesting to report that Ibare and Tijamuchi rivers presented one and two meanders, respectively, with records in the four years.
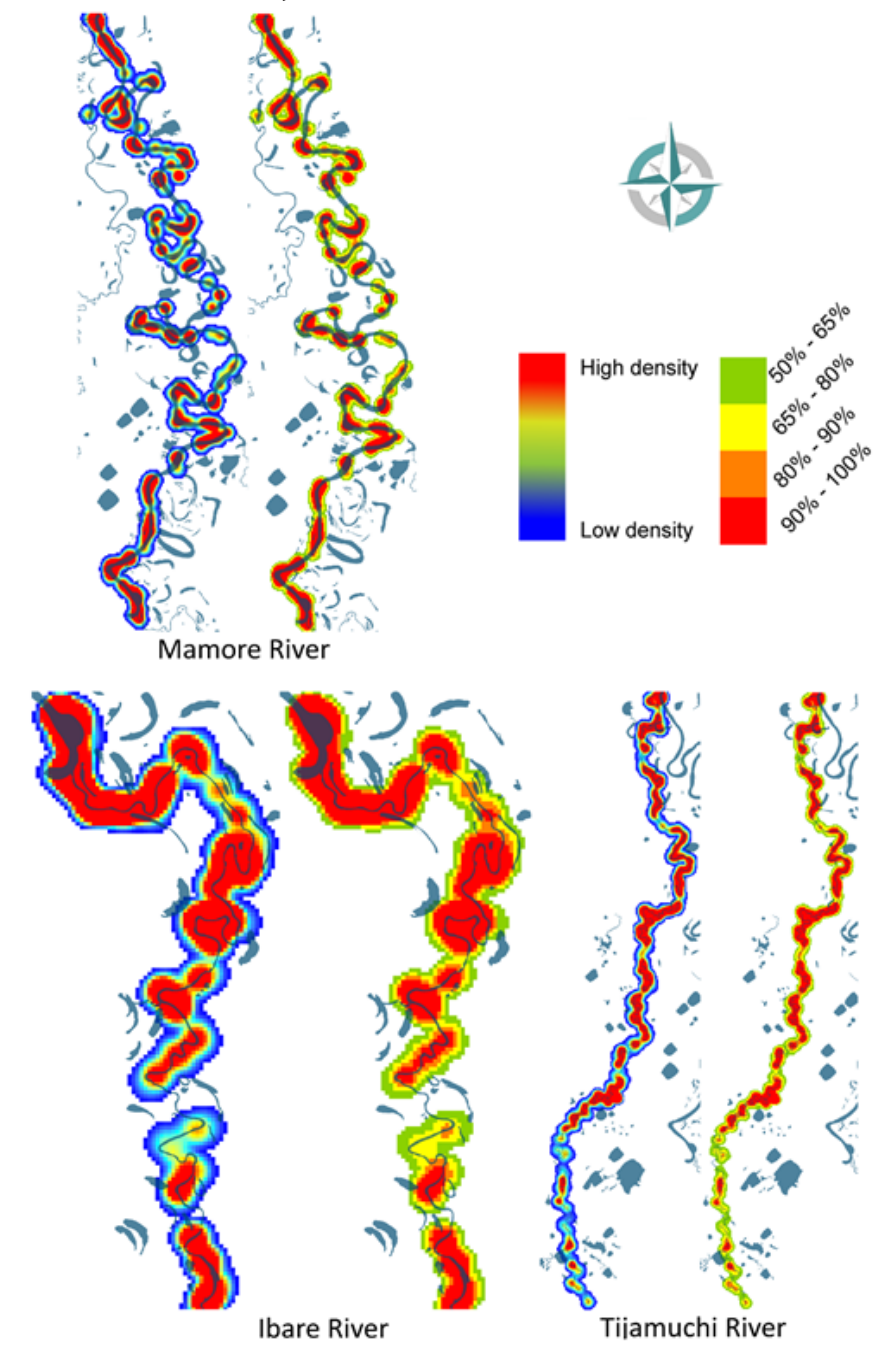

Figure 2. Bufeo presence in the Mamoré, Ibare and Tijamuchi Rivers. Density Kernel Model (left), and Probability of occurrence (right). The three sets of models are not drawn to scale.

\section{Discussion}

Analysis of georeferenced data maps from the accumulated average of five years (seven years for Ibare and four for both Mamoré and Tijamuchi) supports the hypothesis that high density of accumulated bufeos (for all years) coincides with two types of habitats: 1) meanders or curves along the main river course, and 2) confluences. This distribution might be explained by sections characterized by the slow river flow in both habitats (Martin and da Silva 2004b). These habitats are preferred not only for being not high energy-consuming for the bufeos, but also for fish's preference for them (Martin and da Silva 2004b). Confluences have been suggested as areas of high productivity for freshwater dolphins in South America (McGuire and Winemiller 1998) and in Asia 
(Timilsina et al. 2003), housing a high density of fishes, since they provide deep-water environments and shelter (Martin et al. 2004; Gómez-Salazar et al. 2012a; MosqueraGuerra et al. 2015; Trujillo et al. 2019). Also, low-current sites, such as meanders, generally present floating plants that also provide ideal habitat for small fish such as cichlids and catfish (Crampton 1999); these fishes are consumed by bufeos at a much lower energy-cost than in areas with stronger currents. La Manna et al. (2016) indicated that the distribution of a species can be explained by a tradeoff between benefits met in a certain habitat and costs deriving from the exposure to risks. Dolphins, like all other animals, increase their benefits by performing behavioral strategies for staying where the likelihood of prey detection may be higher, and the risk of exposure may be lower.

A second hypothesis suggested that bufeos prefer meanders and confluences for being large size animals (dimensional reason). Meanders and confluences are sites where the river expands width, which makes these environments able to withstand a greater number of individuals compared to the main riverbed, that showed a width between 100 to $150 \mathrm{~m}$, especially during the mating period, which coincides with the dry season. These meanders also have greater depths, which are preferred by the Asian (Braulik and Smith 2019; Baruah et al. 2012) and South American river dolphins (Martin and da Silva 2004b; Aliaga Rossel et al. 2006; Gómez-Salazar et al. 2012a).

The higher probability of encounters with bufeos in meanders may also be due to the sandbars, shallow and with a soft substrate. These characteristics might facilitate

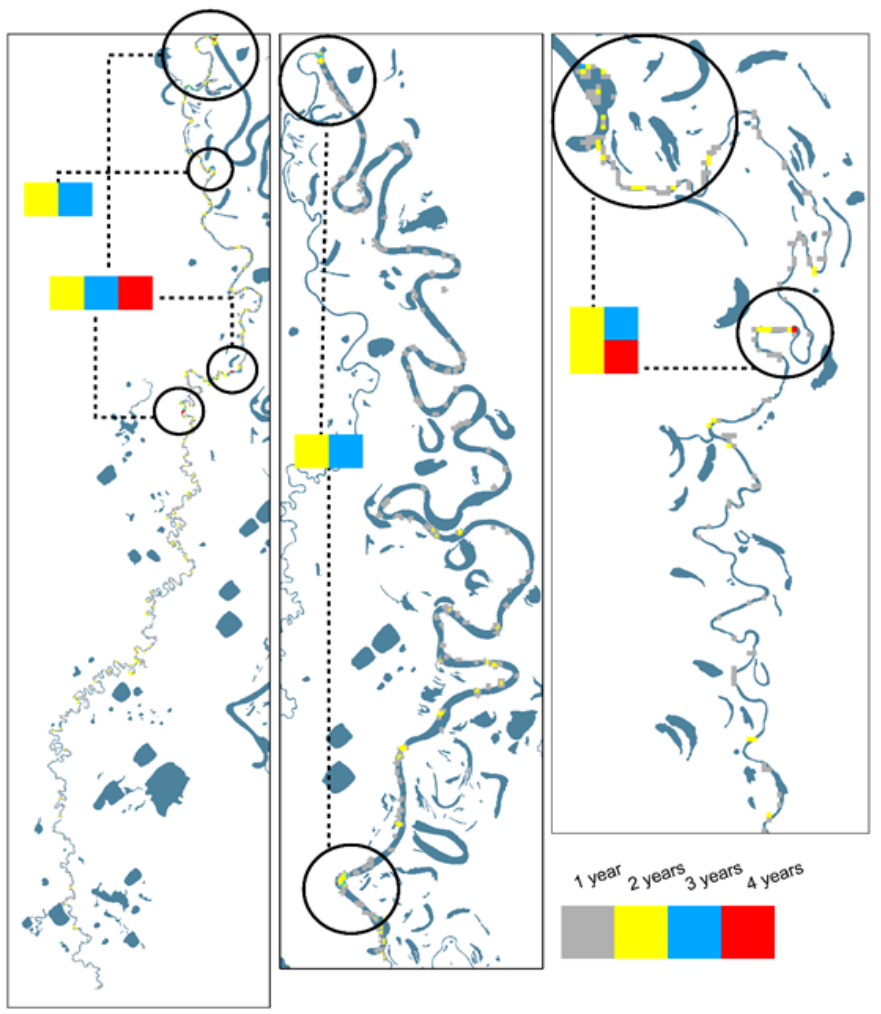

Figure 3. Accumulative occurrence maps showing sites with annual encounter repetitions. Black circles detail the meanders with more than a year of registers. The three sets of models are not drawn to scale. the detection and capture of small preys and provide calm mating areas (McGuire and Winemiller 1998; Trujillo 2000; Aliaga-Rossel and McGuire 2010).

The preference for habitats described here had been suggested and reported in several publications, but in all cases representing a single survey or a short period of time (McGuire and Winemiller 1998; Aliaga-Rossel 2002; Martin and da Silva. 2004a, b; Martin et al. 2004; Aliaga Rossel et al. 2006; McGuire and Henningsen 2007; Gómez-Salazar et al. 2012b; Guizada and Aliaga-Rossel 2016). However, this paper is the first to perform a multitemporal analysis based on that apparent preference, showing even the absence of historical records in certain areas. There were sites in lbare River without records over all the sampled years (density of points null). These values influence the density of the points, reducing the probability of detecting bufeos to less than $80 \%$, even though some are meander sites. The same trend was observed for the Tijamuchi River, where the closer to the headwaters the lower the density of points, modifying the probabilities of sightings to fall with respect to the middle and lower parts of the river. In the Mamoré River, on the other hand, the distribution was more uniform.

The almost insignificant sighting record in Ibare River might be explained by the intensity of the anthropic pressure. This area records corresponded to the section between Puerto Almácen and Puerto Ballivian, area characterized for having high flow and boat traffic for different human activities (e. g., tourism and subsistence fishing). Like with marine dolphins, the presence of the bufeos is probably constrained by disturbance factors such as boat traffic generating an effect of displacement (La Manna et al. 2013). Abdulla and Linden (2008) mention that boat traffic is recognized as one of the major causes of disturbance in aquatic ecosystems, and La Manna et al. $(2014,2016)$ state that characteristics such as frequency and duration strongly affect the amount of time dolphins spend at a site.

The distribution of cetaceans, on a large scale, can be influenced by five factors: 1) physicochemical, 2) climatological, 3) geomorphological, 4) biological, and 5) anthropogenic. However, some physicochemical variables (such as $\mathrm{pH}$, conductivity, water transparency) seem not to influence the distribution of river dolphins, particularly Inia boliviensis (Guizada and Aliaga-Rossel 2016). In contrast, factors such as river bathymetry; differential, seasonal biomass; and mainly the intensity of human activities do influence on the presence of bufeos. For instance, estimating models that incorporate variables of these factors is the most appropriate way to explain and predict the distribution of river dolphins accurately. The identification of important habitat types such as confluences and meanders, which capacity to maintain populations of bufeos over time has been demonstrated, can be the most effective (and practical) way to determine important areas for their survival.

It is important to clarify that, for the Kernel density calculation, one of the parameters used for the estimation is the search radius. For this study, a search radius of $691 \mathrm{~m}$ was used 
to have an area of $1.5 \mathrm{~km}^{2}$ due to dolphin movement. Martin and da Silva (2004a) showed, through satellite tracking, that the Amazon bufeo traveled between 20 to $100 \mathrm{~km}$ per day; some animals have even been seen for weeks using an area of $1 \mathrm{~km}^{2}$. McGuire and Henningsen (2007), using photo ID, reported that the range of movement detected for the species in Bolivia is at least $60 \mathrm{~km}$ or 3 to $10 \mathrm{~km}$ daily. Therefore, the area used was similar to areas found in other regions.

As a conclusion, in three main rivers of the Mamoré River sub-basin, $345.8 \mathrm{~km}$ have been sampled with 30 surveys during a decade of observations. The 10-year database analyzed has allowed to monitor and to identify a clear preference by Bolivian bufeos for confluences and meander habitats in this river-complex in Bolivia.

The identification of these sites, which over time have hosted bufeos in higher concentrations of encounters, are mainly placed into protected areas such as Municipal Protected Area (APM) Ibare-Mamoré, and inside a territory of interest as a future protected area (Tijamuchi). Our data contribute with the main objective of conservation of this protected area and will promote the establishment of a new local Protected Area in the Beni region. We suggest this prompt action, considering that bufeos are a national and regional natural heritage.

\section{Acknowledgments}

We dedicate this paper to the memory of Sydney Anderson. As a junior undergraduate EAR had the fortune of participating of a field trip with the Anderson-Yates expedition. Years later, EAR received a letter from Dr. Anderson - which made a world of difference in his career path -- encouraging him to follow his passion and interest to study bufeos. We also thank J. Salazar-Bravo for his invitation to contribute to this special issue. We thank the Whale and Dolphin Conservation (WDC), Rufford Foundation, and International Foundation for Science (IFS) for the support to Bolivian river dolphin conservation. Thanks to the field assistants in each survey, as well as our gratitude to our outboard motor divers. Special thanks to D. Salas Veizaga for the English review. Earlier versions of this manuscript were improved thanks to the insightful reviews by M. Marmontel (Mamirauá Institute for Sustainable Development, Tefé, Brazil) and an anonymous reviewer.

\section{Literature cited}

Abdulla, A., and O. Linden. 2008. Maritime traffic effects on biodiversity in the Mediterranean Sea. Review of impacts, priority areas and mitigation measures. Malaga, Spain: IUCN Center for Mediterranean Cooperation.

Albert, J. S., AND R.E. Reis. 2011. Introduction to neotropical freshwaters. Pp. 13-14 in Historical biogeography of neotropical freshwater fishes (Albert, J. S, and R. E. Reis, eds). University of California Press. Berkeley, U.S.A.

Aliaga-Rossel, E. 2002. Distribution and abundance of the river dolphin (Inia geoffrensis) in the Tijamuchi River, Beni, Bolivia. Aquatic mammals 28:312-323.
Aliaga-Rossel, E., and L. A. Guizada. 2020. Four decades of research on distribution and abundance of the Bolivian river dolphin Inia geoffrensis boliviensis. Endangered Species Research 42:151-165.

Aliaga-Rossel, E., and T. Mcguire. 2010. Iniidae. Pp. 535-570 in Distribución, ecología y conservación de los mamíferos medianos y grandes de Bolivia. (Wallace, R. B., H. Gómez, and Z. R. Porcel, eds). Centro de Difusión Simón I. Patiño. Santa Cruz, Bolivia.

Aliaga-Rossel, E., T. Mcguire, and H. Hamilton. 2006. Distribution and encounter rates of the river dolphin (Inia geoffrensis boliviensis) in the central Bolivian Amazon. Journal of Cetacean Research and Managment 8:87-92.

Aliaga- Rossel E, F. Trujllo, and E. Hoyt. 2014. Buenas prácticas para la observación responsable del bufeo boliviano (Inia boliviensis). Gobernación Autónoma del Departamento del Beni.

Baruah, D., L. P. Hazarika, B. Bakalial, S. Borah, R. Dutta, and S. Biswas. 2012. A grave danger for the Ganges dolphin (Platanista gangetica Roxburgh) in the Subansiri River due to a large hydroelectric project. The Environmentalist 32:85-90.

Best, R., AND V. DA-Silva. 1993. Inia geoffrensis. Mammalian Species 426:1-8.

Braulik, G. T., AND B. D. Smith. 2019. Platanista gangetica (amended version of 2017 assessment). The IUCN Red List of Threatened Species 2019: e.T41758A151913336. https://dx.doi.org/10.2305/IUCN.UK.2017-3.RLTS. T41758A151913336.en. Consulted on 16 September 2020.

CRAmpton, W. 1999. Os peixes da Reserva Mamirauá: diversidade e história natural na planície alagável da Amazônia. Estratégias para Manejo de Recursos Pesqueiros em Mamirauá. Sociedade Civil Mamirauá/CNPq. Brasília, Brazil.

Da Silva, V. M. F., ANd A. Martin. 2000. A study of the boto, or Amazon river dolphin (Inia geoffrensis), in the Mamirauá Reserve, Brazil: operation and techniques. Pp. 121-131 in Biology and Conservation of Freshwater Dolphins in Asia (Reeves, R. R., B. D. Smith, and T. Kasuya. eds.). The International Union for Conservation of Nature-IUCN. Gland, Switzerland and Cambridge, U. K.

Da Silva, V., F. Trujlllo, A. Martin, A. Zerbinı, A. N. Crespo, E. Aliaga-Rossel, and R. Reeves. 2018. Inia geoffrensis. The IUCN Red List of Threatened Species 2018: e.T10831A50358152. https://dx.doi.org/10.2305/IUCN.UK.2018-2.RLTS. T10831A50358152.en. Consulted on 16 September 2020.

Gómez-Salazar, C., F. Trujlllo, and H. Whitehead. 2011. Population size estimates of pink river dolphins (Inia geoffrensis) using mark-recapture methods on photoidentification. Latin American Journal of Aquatic Mammals 9:40-47.

Gómez-Salazar, C., M. Portocarrero-Aya, and H. Whitehead. 2012a. Population, density estimates and conservation of river dolphins (Inia and Sotalia) in the Amazon and Orinoco river basins. Marine Mammal Science 28:124-153.

Gómez-Salazar, C., F. Trujlllo, and H. Whitehead. 2012b. Ecological factors influencing group sizes of river dolphins (Inia geoffrensis and Sotalia fluviatilis). Marine Mammal Science 28:124-142.

Guizada, L., And E. Aliaga-Rossel. 2016. Population data of the Bolivian river dolphin (Inia boliviensis) in Mamore River, Upper Madeira Basin. Aquatic Mammals 42:330-338. 
Guyot, J. L. 1993. Hydrogéochimie des Fleuves de l'Amazonie Bolivienne. ORSTOM, Paris.

Hrbek, T., V. Da-Silva, N. Dutra, W. Gravena, A. Martin, and I. PIREs. 2014. A new species of river dolphin from Brazil or: How little do we know our biodiversity. PLOS One 9: e83623.

La Manna, G., M. Manghi, G. Pavan, F. Lo Mascolo, and G. Sarà. 2013. Behavioural strategy of common bottlenose dolphins (Tursiops truncatus) in response to different kinds of boats in the waters of Lampedusa Island (Italy). Aquatic Conservation: Marine and Freshwater Ecosystems 23:745-757.

La Manna, G., M. Manghi, and G. Sará. 2014. Monitoring the habitat use of common Bottlenose Dolphins (Tursiops truncatus) using passive acoustics in a Mediterranean marine protected area. Mediterranean Marine Science 15:327-337.

La Manna, G., F. Ronchetti, And G. Sarà. 2016. Predicting common bottlenose dolphin habitat preference to dynamically adapt management measures from a Marine Spatial Planning perspective. Ocean and Coastal Management 130:317-327.

Martin, A. R., And V. M. F. DA Silva. 2004a. Number, seasonal movements, and residency characteristics of river dolphins in an Amazonian floodplain lake system. Canadian Journal of Zoology 82:1307-1315.

Martin, A. R., And V. M. F. Da Silva. 2004b. River dolphins and flooded forest: seasonal habitat use and sexual seggregation of botos (Inia geoffrensis) in an extreme cetacean environment. Journal of Zoology, London 263:295-305.

Martin, A. R., V. M. F. Da Silva, and D.L. Salmon. 2004. Riverine habitat preferences of botos (Inia geoffrensis) and tucuxis (Sotalia fluviatilis) in the central Amazon. Marine Mammal Science 20:189-200.

Mcguire, T., And E. Aliaga-Rossel. 2007. Seasonality of reproduction in amazon river dolphins (Inia geoffrensis) in three major river basins of South America. Biotropica. 39:129-135.

Mcguire, T., and E. Aliaga-Rossel. 2010. Ecology and conservation status of river dolphins Inia and Sotalia in Peru. Pp. 57-83 in The action plan for south american river dolphins 2010 - 2020 (Trujillo F., E., P. Crespo, and A. Van Damme, eds.). WWF, Fundación Omacha, WDS, WDCS, Solamac. Bogotá, Colombia.

Mcguire, T. L., And T. Henningsen. 2007. Movement patterns and site fidelity of river dolphins (Inia geoffrensis and Sotalia fluviatilis) in the Peruvian Amazon as determined by photoidentification. Aquatic Mammals 33:359.

Mcguire, T., AND K. O. Winemiller. 1998. Occurrence patterns, habitat associations and potential prey of the river dolphin, Inia geoffrensis, in the Cianuco river, Venezuela. Biotropica 30:625-638.

Mosquera-Guerra, F., C. Parra, F. Trujillo, A. M. JimenezOrtega, And H. Mantilla-Meluk. 2015. Valoración estacional de las amenazas contra la conservación de Inia geoffrensis humboltdltiana (Cetartiodactyla Iniidae) en la cuenca del río Meta, Colombia. Therya 6:371-388.

Pillerı, G., AND M. Gihr. 1977. Observations on the Bolivian (Inia geoffrensis d' Orbigny, 1834) and the Amazonian Bufeo (Inia geoffrensis de Blainville, 1817) with description of a new subspecies (I. geoffrensis humboldtiana). Investigations on Cetacea 8:11-76.
R Core Team. 2017. R: A language and environment for statistical computing. Vienna, Austria: R Foundation for Statistical Computing.

Reeves, R. R., And S. Leatherwood. 1994. Dolphins, Porpoises and Whales 1994-1998 Action plan for the conservation of cetaceans. IUCN Species Survival Commission. Gland, Switzerland.

Smith, B. D., G.T. Braulik, And R. Sinha. 2012. Plantanista gangetica ssp. gangetica. The IUCN Red List of Threatened Species: e.T41756A17627639. http://dx.doi.org/10.2305/ IUCN.UK.2012.RLTS.T41756A17627639.en. Consulted on on 14 August 2020.

Timilsina, N., B. Tamang, and N. Baral. 2003. Status and conservation of Gangetic dolphin (Plantanista gangetica) in the Karnali river, Nepal. Tigerpaper 30:8-22.

Trusillo, F. 2000. Habitat use and social behaviour of the freshwater dolphin Inia geoffrensis (de Blainville 1817) in the Amazon and Orinoco basins. University of Aberdeen, Scotland. Doctoral Theses. 157 p.

Trujillo, F., E. Crespo, P. Van-Damme, and J. Usma. 2010a. The Action plan for south american river dolphins 2010 - 2020. WWF, Fundación Omacha, WDS, WDCS, Solamac. Bogota, Colombia.

Trujillo, F., M. Portocarrero-Aya, C. Gómez-Salazár, M. C. Diazgranados, L. Castellanos-Mora, M. Ruíz-García, and S. Caballero. 2010b. Conservation status of river dolphins Inia geoffrensis and Sotalia fluviatilis in the Amazon and Orinoco River Basins in Colombia. Pp 27-55 in The Action Plan for South American River Dolphins 2010 - 2020 (Trujillo F., E., P. Crespo, and A. Van Damme, eds.). Bogotá, D.C., Colombia: WWF, Fundación Omacha, WDS, WDCS, Solamac.

Trujillo, F., F. Mosquera-Guerra, and N. Franco. 2019. Delfines de río: especies indicadoras del estado de salud de los ecosistemas acuáticos de la Amazonia y la Orinoquía. Revista de la Academia Colombiana de Ciencias Exatas Fisicas y Naturales 43:199-211.

Associated editor: Jorge Salazar Bravo

Submitted: March 24, 2020; Reviewed: April 16, 2020;

Accepted:August 8, 2020; Published on line: September 26, 2020. 


\title{
Appendix 1
}

Script developed in the writeRaster function to create a bufeo occurrence probability per cell:

\author{
library(raster) \\ \#\#Import the images by river per year \\ raster_river<-raster('nameRaster') \\ \#\#Graphing the raster \\ plot(raster_river) \\ \#\#Summary of values per cell \\ summary(raster_river)
}

\#\#A new empty raster is created that is the same size as the initial raster

$$
\begin{aligned}
& \text { newraster<-raster_river } \\
& \text { newraster[] <- NA } \\
& \text { getValues(raster_river) }
\end{aligned}
$$$$
\text { newraster2<-getValues(raster_river) }
$$

\#\# probability values of a normal distribution on the layer specifying the mean of the raster and its standard deviation

pnorm(newraster2, mean (newraster2), sd = \#value SD raster_river)

values (newraster) <-pnorm (newraster 2 , mean(newraster2), sd = \#value SD raster_river)

\#\#Graph of the new raster

plot(newraster)

\#\#Save the new raster with probability of occurrence values

writeRaster(newraster, file='name') 